\title{
HENRYK BUJAK
}

KAMILA NOWOSAD

AGNIESZKA LACKA

Uniwersytet Przyrodniczy we Wrocławiu, Katedra Genetyki, Hodowli Roślin i Nasiennictwa

Kierownik Tematu: prof. dr hab. Henryk Bujak Uniwersytet Przyrodniczy we Wrocławiu, Katedra Genetyki,

Hodowli Roślin i Nasiennictwa, 50-363 Wrocław, Plac Grunwaldzki 24A, tel. 713201829,

e-mail: henryk.bujak@upwr.edu.pl

Prace zostały wykonane $w$ ramach badań podstawowych na rzecz postęp biologicznego $w$ produkcji roślinnej na podstawie decyzji Ministra Rolnictwa i Rozwoju Wsi nr HOR.hn.802.14.2018, Zadanie nr 22.

\section{Poszukiwanie źródeł genetycznej odporności na mączniaka i rdzę w kolekcji linii, rodów i odmian żyta}

\section{Search for genetic sources to powdery mildew and brown rust resistance in rye inbred lines and varieties collection}

Słowa kluczowe: materiały hodowlane, mączniak prawdziwy, rdza brunatna, odmiany, żyto

Celem badań była próba znalezienia efektywnych genów odporności na mączniaka prawdziwego i rdzę brunatną u różnych genotypów żyta ozimego oraz weryfikacja markerów molekularnych przydatnych do ich identyfikacji. Wyniki badań pozwoliły na identyfikację i sprawdzenie efektywności działania genów odporności na obecnie występujące rasy mączniaka prawdziwego oraz rdzy brunatnej. Do analizy molekularnej pozwalającej na identyfikację posiadanych genów odporności wykorzystano opracowane i pozyskane $\mathrm{z}$ literatury sekwencje starterowe sprzężone z najbardziej efektywnymi genami odporności na wymienione patogeny żyta.

Materiał badawczy w 2018 roku stanowiły zgromadzone w kolekcji własnej homozygotyczne linie wsobne oraz przesłane przez hodowców genotypy żyta. Oceny odporności genotypów żyta ozimego na porażenie przez mączniaka prawdziwego i rdzę brunatną prowadzono w warunkach sztucznej inokulacji oraz w warunkach infekcji polowej. W trakcie prowadzonych w 2018 roku badań przetestowano ponad 180 obiektów żyta ozimego w doświadczeniach infekcyjnych, w kontrolowanych warunkach, w celu poszukiwania genotypów na odpornych zarówno na mączniaka prawdziwego, jak i na rdzę 
brunatną. Dodatkowo w warunkach polowych zweryfikowano odporność na patogeny około 180 linii wsobnych żyta.

Wyniki przeprowadzonych doświadczeń pozwoliły wyselekcjonować wyprowadzone przez hodowców materiały pod kątem ich odporności zarówno na mączniaka prawdziwego, jak i rdzę brunatną. Niestety wśród otrzymanych materiałów wystąpiła niewielka liczba genotypów żyta odpornych na poszczególne patogeny, co świadczy o tym, że istnieje potrzeba jest dalszych badań i wyprowadzenia genotypów o pożądanej odporności na mączniaka prawdziwego i rdzę brunatną oraz genotypów posiadających odporność na obydwa patogeny jednocześnie. Liczba genotypów odpornych na poszczególne patogeny zależała od roku badań tzn. przesłanych przez hodowców materiałów oraz wirulencji zebranych izolatów patogenów służących do infekcji. Stwierdzono bark korelacji pomiędzy porażeniem obiektów przez mączniaka prawdziwego i rdzę brunatną, co spowodowało że udało się wyselekcjonować niewielką liczbę form odpornych na oba patogeny. Wyprowadzone nowe genotypów o podwyższonej odporności na mączniaka prawdziwego i rdzę brunatną zostały przekazane zainteresowanym hodowcom.

Sprawdzono przydatność markerów molekularnych do identyfikacji genów odporności na mączniaka prawdziwego i rdzę brunatną u badanych genotypów żyta. Ponieważ dla żyta nie było opracowanych specyficznych markerów molekularnych sprzężonych z genami odporności na mączniaka prawdziwego $(P m)$, na początku wykorzystywano znane z literatury, ale opracowane dla innych zbóż sekwencje starterów, które zostały i sprawdzone u żyta. Uzyskano także nowe specyficzne startery dla żyta. W realizowanym projekcie badawczym sprawdzono funkcjonowanie u żyta starterów dających markery molekularne sprzężone z następującymi genami Pm1, Pm2, Pm3a,Pm3b, Pm3c, Pm3d, Pm3e, Pm3f, Pm3g, Pm4, Pm4a, Pm13, Pm16, Pm17, Pm34, Pm43. Wyniki analiz molekularnych wykazały przydatność markerów mikrosatelitarnych związanych z genami $P m 4$ i $P m 34$ do poszukiwania genów odporności na mączniaka prawdziwego u żyta ozimego ponieważ charakterystyczne produkty amplifikacji występowały jedynie $\mathrm{w}$ grupie genotypów żyta odpornych.

Do identyfikacji genów odporności na rdzę brunatną wykorzystano markery sprzężone z genami odporności opracowane dla żyta oraz sprawdzono przydatność markerów opracowanych dla innych zbóż. Wykorzystano następujące startery stworzone na bazie sekwencji genów związanych z odpornością na rdzę brunatną $\operatorname{Lr1} 1, \operatorname{Lr} 4, \operatorname{Lr} 5, \operatorname{Lr} 6, \operatorname{Lr} 7, \operatorname{Lr} 9$, Lr13, Lr19, Lr 24, Lr25, Lr26, Lr35, Lr36, Lr46, Lr47, Lrk 10 i Lr $r_{\text {Satu }}$ oraz opracowane na bazie sekwencji pszenicy TC76051, TC72745, TC77841 Spośród starterów związanych z genami odporności na rdzę brunatną można wyróżnić te, które pozwoliły na wykazanie obecności genów odporności u analizowanych genotypów żyta ozimego, są to startery specyficzna dla genów $L r 9, \operatorname{Lr} 36$ i $L r 47$.

Markery dla obydwu patogenów wymagają jednak sprawdzenia na większej liczbie genotypów odpornych, aby można je było rekomendować do weryfikacji genów odporności na rdzę brunatną i mączniaka prawdziwego w materiałach hodowlanych żyta ozimego. Wyniki uzyskane $\mathrm{w}$ wyniku realizacji zadania badawczego mogą być bezpośrednio wprowadzone do programów hodowli żyta w celu uzyskania bardziej odpornych odmian na rdzę brunatną oraz mączniaka prawdziwego. 